\title{
Sport: The Treasure of Temperance
}

\author{
Jernej Pisk
}

University of Ljubljana, Slovenia

ABSTRACT

The modern lifestyle, with its emphasis on enjoyment and immoderation, could lead a human being to the point where he is not a master of himself anymore. Inner desires and outer pressures force a man to take those actions that are not in accordance with his rational human nature and that are not good for him. According to the classical philosophical view of Socrates, Plato and Aristotle, this clearly shows the inner slavery of modern man. Temperance, moderation or asceticism today seem old fashioned and unnecessary virtues; nevertheless, it is obvious that many problems of modern societies have roots in the absence of these virtues. These problems include a high percentage of obese population, different addictions and other health problems concerning the immoderate life style. It seems that nowadays enjoyment is the highest imperative for the individual and for society as a whole. However, these days it is possible to recognize the revival of these virtues. This paper points out the case of sport where these virtues are still cultivated and highly appreciated. At first this may seem somehow strange, because many times sport is perceived as connected with pleasure, fun and excess, but in reality sport demands much of participants. It could be even said that professional athletes are modern ascetics, and a big part of recreational sport is all but not enjoyment. In conclusion we can assert that virtues acquired in the field of sport can indeed help a human being to live a better life in general.

KEYWORDS sport, temperance, virtue, philosophy of sport, education

\section{Introduction}

The role of temperance in the modern world cannot be denied. As a one of the four cardinal virtues, it is tightly connected with human nature and has a great importance for a good life of a human being as well as for society as a whole ${ }^{1}$. Intemperance or immoderation leads a human being to

\footnotetext{
1 "This particular intellectual framework, the formula which is called the "doctrine of virtue," was one of the great discoveries in the history of man's self-understanding, and it has continued to be part and parcel of the European mind. It has become a basic component of the European consciousness, as the result of centuries of persistent intellectual endeavor by all the creative elements of the emerging West, both the Greeks (Plato, Aristotle) and the Romans (Cicero, Seneca), both Judaism (Philo) and Christianity (Clement of Alexandria, St. Augustine). [...] The doctrine of virtue, has things to say about this human person; it speaks both of the kind of being which is his when he enters the world, as a consequence of his createdness, and the kind of being he ought to strive toward and attain to by being prudent, just, brave, and temperate. [...] Its aim is to clear a trail, to open a way. [...] That team of four, the basic virtues, which, as a fine classical phrase put it, can enable man to attain the furthest potentialities of his nature." (Pieper 1965, xi-xii).
} 
the point where he is no longer the master of himself. According to the classical philosophical views of Socrates, Plato and Aristotle, this clearly shows the inner slavery of modern man, that modern man is often the slave of his own desires. This situation can be recognized in numerous cases in contemporary society including the high rate of obesity in the population, different addictions, and other health problems concerning an immoderate life style. In the immoderate lifestyle, modern man can lose characteristics essential for him to be a free and self-determining being. We can say that some higher qualities proper to human beings are lost in immoderation and man is in a sense degraded to the level of an animal; there are, however, important differences between immoderate man and animal.

In this paper we will not stop at a diagnosis of contemporary situation or the contemporary problems caused by immoderation, but we will try to show one possible solution, one possible way that can help modern man preserve his dignity as a free, moral person. We will argue that nowadays sport has great power to help accomplishing this task.

\section{The role and place of temperance in human nature}

The final aim of human life is to attain happiness, that is, happiness in this world as emphasized by Aristotle, or also happiness in the other word (afterlife) as emphasized by Aquinas ${ }^{2}$. But to attain happiness a human being must live in accordance with his innate human nature. But what is this human nature? We will present some essential characteristics of human nature as Plato had exposed them, and were further developed by other classical Greek and Christian philosophers. Its characteristic is that it recognizes in human beings different capabilities that can cooperate or work one against other. To put in order tensions between these capabilities special facilities are needed. These are known as the four cardinal virtues: prudence, justice, fortitude and temperance. Because Plato's classical vision of human nature is constructed around the four cardinal virtues (which includes temperance), it has a special role for our inquiry.

\section{Temperance in Plato, Aristotle and Aquinas}

Plato is one of the main sources for the dualist view, according to which the human soul or mind is a nonmaterial entity that exists apart from the body. The soul is the higher element in human nature, while the body is the lower. In Plato's view of human nature, the tripartite structure of the soul has special importance. Plato recognized that there are three different faculties of the human soul or three different aspects of our mental nature. The first is the one that enables us to think (reason). Second is the one that enables us to be excited or to be angry about something (passion). Third is the one that enables in us the desire for pleasure and feeding (appetite) (Stevenson and Haberman 2009, p. 78). We can recognize the existence of internal conflicting tendencies in ourselves, even if we take a materialistic, evolutionary view of human beings as a kind of an animal with a well-developed brain. Because the same faculty cannot produce contradictory effects, it is not possible that only one faculty would execute all three activities; there must be more different faculties of the soul. In Plato's words: "The difficulty is to determine whether the several principles are one or three; whether, that is to say, we reason with one part of our nature, desire with another, are angry with another, or whether the whole soul comes into play in each sort of action. This enquiry, however, requires a very exact definition of terms. The same thing in the same relation cannot be affected in two opposite ways"3.

Our everyday experience tells us that it is often possible to recognize in us a desire for some object but, at the same time, there is another force within us trying to keep us away from the object of desire. For example, consider a mental conflict or inhibition, such as when someone is thirsty but does

\footnotetext{
${ }^{2}$ It can be said that all the important classical philosophers have agreed on this, until the modern age. See Aristotle's Nicomachean Ethics as a paradigmatic example of this position.

3 Plato, Republic, 436. (We will use the universal international standard for citing the works of classical philosophers, such as Plato, Aristotle, Aquinas etc. We will therefore cite them in the footnotes.)
} 
not drink available water because he believes it is poisoned. That is the role of reason. And there is another aspiration in us that makes us excited or angry. It is not reason and it is not desire. But it can be in the service of the former or latter (Reale 2002, p. 220).

And where is the place of temperance? Temperance is virtue that enables us to attain a kind of order, to be master over pleasures and desires in us. It is the virtue that enables the worst part in us to be subordinate to the best part. In Plato's words: "More than the preceding virtues temperance suggests the idea of harmony. Some light is thrown upon the nature of this virtue by the popular description of a man as 'master of himself' - which has an absurd sound, because the master is also the servant. The expression really means that the better principle in a man masters the worse" ${ }^{\prime 4}$.

For Plato temperance has especially three meanings: to master desires for food, drink and sex. The importance of temperance for a good human life lies therefore in the fact that the desires for pleasures are usually a very strong force in human beings ${ }^{5}$. Often it is hard to cope with them; therefore special virtue - temperance - is needed to cultivate them. Only then does the better in the soul takes authority over the worse.

Aristotle's anthropology is in essence derived from Plato. As with Plato, Aristotle believes that the essence of human being is in its soul or $\operatorname{mind}^{6}$. Therefore the human values could not be different from those found in Plato. True values concern the inner life of the human being's soul, and not outer life, such as wealth or the pleasures of the body. The final aim of the human life is to attain happiness. But to attain it, it is necessary that the soul act in accordance with the virtues. For Aristotle virtue can be defined as "a state of character concerned with choice, lying in a mean, i.e. the mean relative to us, this being determined by a rational principle, and by that principle by which the man of practical wisdom would determine it. Now it is a mean between two vices, that which depends on excess and that which depends on defect ${ }^{7}$.

Similar to Plato, Aristotle also points out that "temperance is a mean with regard to pleasures". Many contemporary social problems arise from inappropriate indulgence in food, drink, and/or sex. Temperance is the Aristotelian virtue governing these three things. Aristotle limits temperance to the pleasures of touch and taste ${ }^{9}$, but non-bodily pleasures are excluded from the sphere of temperance ${ }^{10}$. The parameters of temperance are objects, occasions, and amounts. Temperate people desire the right objects on the right occasions to the right degree, while the intemperate go in the wrong direction with respect to these parameters (Curzer 1997, p. 12).

As for the ancient Greeks in general, and for Aristotle also, to have a virtue means that its natural capabilities are fulfilled. It can be fulfillment of object, animals or human beings. Virtue is therefore completion of innate nature of a being. "Excellence is a completion; for each thing is complete and every substance is complete, when in respect of the form of its proper excellence it lacks no part of its natural magnitude" ${ }^{\prime 1}$. The ability of the human being to be virtuous is laid down in his human nature, but he must be well educated to fulfill these capacities (Kocijančič 2002, p. 1100).

Christian thinkers adapted the classical ancient view on human nature and complemented it with some special characteristics derived from revealed theology (the Bible). Therefore it is not surprising that Christian authors exposed a similar understanding of human virtues to those found in the pagan

\footnotetext{
${ }^{4}$ Plato, Republic, 430.

${ }^{5}$ Plato, Republic, 441d-442d.

${ }^{6}$ Aristotle, Nicomachean Ethics, 1178a 2-3.

${ }^{7}$ Aristotle, Nicomachean Ethics, B 6.

${ }^{8}$ Aristotle, Nicomachean Ethics, 1117b 24-25.

${ }^{9}$ Aristotle, Nicomachean Ethics, 1118a 2-10.

${ }^{10}$ Aristotle, Nicomachean Ethics, 1117b 31-1118a.

${ }^{11}$ Aristotle, Metaphysics, 1021b 20.
} 
philosophers ${ }^{12}$. Aquinas defined virtue as a habit ${ }^{13}$. The idea of a virtue as a habit and habit itself as a second nature was commonplace for the Romans as well as for the Greeks (Kent 2002, p. 116).

Aquinas declared, "A habit is that whereby we act when we will"14. Aquinas argues that we can always refuse to act in accordance with our habits and can always choose to act against our habits. From the essential character of a habit alone, it is clear that a habit is principally related to the will ${ }^{15}$. In the Aquinas view, human beings are blamed for tantrums, fits of gluttony, and other such actions because we never act from passions without the consent of our wills. Animals could not fairly be blamed for apparently similar behavior because they lack the power of will. They are not, as human beings are, 'masters' of their own actions (Kent 2002, p. 119).

As for Plato and Aristotle, temperance for Aquinas is directed toward pleasures: "Man naturally desires pleasures that are becoming to him. Since, however, man as such is a rational being, it follows that those pleasures are becoming to man which are in accordance with reason. From such pleasures temperance does not withdraw him, but from those which are contrary to reason. Wherefore it is clear that temperance is not contrary to the inclination of human nature, but is in accord with it. It is, however, contrary to the inclination of the animal nature that is not subject to reason"16. The purpose of temperance is the inside order. Because temperance is directed toward the individual, itself it is not a realization of a good. But together with fortitude it is a necessary precondition for realization of the virtues of prudence and justice. This is the same as in sport.

Therefore, temperance can lead a human being to the fulfillment of his given nature, while everything that is contrary to this nature is vicious. But nature has attached delight to the activities that are necessary for the life of $\operatorname{man}^{17}$. Aquinas therefore rejected senselessness or denial of natural pleasures, except in special occasions: "It is to be observed however that sometimes it is praiseworthy, or even necessary, for a particular purpose, to abstain from the delights that are attendant upon such activities. Thus for the health of their bodies some abstain; and again for the execution of some charge, as athletes and soldiers have to abstain from many delights to fulfill their task"18.

\section{Some examples of temperance from the history of sport}

At first glance it seems that there is no place for temperance in a sport. Namely, what is sport, especially competitive (or elite) sport, if not exaggeration? Therefore it is often said that a term more suitable for modern sport could be the so-called 'ethics of maximum' (Hosta 2007, p. 60) and not the ethics of moderation or the golden mean which temperance includes. But if we take a closer look, it can be seen that the athletes cannot succeed without renouncing many unnecessary things. Reason must take control over emotions, bodily desires and pains. Therefore it is obvious that temperance has an important role in sport as well as in any human conduct. We already cited the quote from Aquinas where he said, "athletes and soldiers have to abstain from many delights to fulfill their task"19.

There are few other examples of the role of temperance in sport from antiquity. Plato wrote about the role of temperance and asceticism in sport in his Laws: "Have we not heard reports about

\footnotetext{
${ }^{12}$ For example, see Augustine's description of temperance: "What is the activity of virtue here but a perpetual war with vices? - not external vices but internal, not alien but clearly our very own - a war waged especially by what is called sophrosyne in Greek and temperantia in Latin which bridle our fleshly lust lest they drag our will to consent to crimes of every sort" (De civitate dei,19. 4.).

${ }^{13}$ Aquinas, Summa Theologicae, Ia IIae, q. 55, a. 4.

${ }^{14}$ Aquinas, Summa Theologicae, Ia IIae, q. 49, a. 3.

${ }^{15}$ Aquinas, Summa Theologicae, Ia IIae, q. 50, a. 5.

${ }^{16}$ Aquinas, Summa Theologicae, IIa IIa, q. 141, a.1.

${ }^{17}$ Aquinas, Summa Theologicae, IIa IIa, q. 142, a.1.

${ }^{18}$ Aquinas, Summa Theologicae, IIa IIa, q. 142, a.1.

${ }^{19}$ Aquinas, Summa Theologicae, IIa IIa, q. 142, a. 1.
} 
Ikkos, citizen of Tarentum, because of his victory at Olympia in pentathlon in $444 \mathrm{BC}$ and other games? As the story goes, because of his desire to win, his ability, and courage in his heart along with self-control, he never touched a woman, or a boy either, in the entire course of his training. The same story exists about Krison, Astylos, Dipompos, and many others" ${ }^{\text {20. }}$.

And similar stories are ascribed to other ancient athletes. Dio Chrysostomos who lived in the first and second centuries A.D. wrote about the special virtues athletes must have: "The most admirable thing of an athlete is not only to be superior concerning his competitor, but to have control over fatigue, heat, gluttony and sexual desires. Namely, a man who does not want to give up in front of competitor, must not give up to those things" ${ }^{21}$.

The wish to become an Olympic winner demanded much from athletes. The athletes had to give themselves up to the instructions of the coach, just like to the instructions from a doctor: "You will have to obey instructions, eat according to regulations, keep away from desserts, exercise on a fixed schedule at definite hours, in both heath and cold; you must not drink cold water nor can you have a drink a wine whenever you want. [...] And after all that there are times when you lose"22.

Obviously, the training of athletes demands various kinds of restrictions and self-denial, but it is always for the purpose of competing in order to win. And this is worth price to be paid: "You spoke about the pleasures he [the athlete] has missed. Whoever enjoyed more pleasure than an athlete eager to win who was always victorious and who knew that he was an object of admiration?"23

Also St. Paul used the experiences of asceticism in sport and applies the concept to the Christian life:

"You know that while all the runners in the stadium take part in the race, the award goes to one man. In that case, run so as to win! Athletes deny themselves all sorts of things. They do this to win a crown of leaves that withers, but we a crown that is imperishable. I do not run like a man who loses sight of the finish line. I do not fight as if I were shadowboxing What I do is discipline my own body and master it, for fear that after having preached to others I myself should be rejected" (I Corinthians 9: 24-27)

It is not surprising, therefore, that early Christian writers used the term 'athlete' as a synonym for 'martyr' (Sweet 1987, vii). The tight connection between temperance and sport can be shown also through the historical development of the term asceticism. The term 'asceticism' is derived from the Greek word askesis, which referred originally to the sort of exercise, practice or training in which athletes engage (Quinn 1998). Asceticism may be characterized as a voluntary, sustained and systematic program of self-discipline and self-denial in which immediate sensual gratification is renounced in order to attain some valued spiritual or mental state. Nevertheless a modern understanding of asceticism is usually connected with different religious practices, whereas the original meaning was connected with the rigorous training of athletes.

But asceticism has not found favor with most of those who subscribe to the worldview of secular modernity. It has been criticized by some important modern philosophers. Bentham (1996) argued that humans cannot consistently practice asceticism because they are by nature motivated to seek pleasure and to avoid pain. Typically, however, ascetics do not seek pain for its own sake but rather as a means for achieving something they take to be a greater good such as winning the race or union with God. Humans seek painful medical treatment for the sake of their health. This demonstrates that humans can practice asceticism, including the infliction of pain on themselves, if

\footnotetext{
${ }^{20}$ Plato, Laws 839e-840a.

${ }^{21}$ Dio Chrysostomos, Discourse 28. (Sweet 1987, 76).

${ }^{22}$ Epictetus, Discourses 15.2-5. (Sweet 1987, 114).

${ }^{23}$ Dio Chrysostomos, Discourse 28. (Sweet 1987, 76).
} 
they perceive doing so as a means to some good end. At this point it is necessary to point out that two quite different conceptions of asceticism emerged in history. "One of these preserves original meaning of discipline of the body for some ultimate purpose. [...] The other conception distrust the body altogether. Asceticism has then as its function not the training but the destroying of the body or the negation of its importance" (Hall 2003, p. 63). The former can also be found, among other areas, in sport while the latter is more characteristic for some extreme (fundamental) religious practices.

\section{Sport as a source of temperance for modern man}

We have already seen that since ancient times sport practices have been great means of cultivating temperance inside human beings. But why does sport have this 'power' to force (modern) human being to be temperate or moderate while other means, like preaching, do not have this power? It seems that there is the undeniable role of body. Sport, in general, can be defined as a special kind of human bodily activity. The body has its own demands, which cannot be denied. A human being is not just a mind, but also its body - a union of body and soul. As a rational or spiritual being it is possible to exceed some limitations of the body, but after all, the body again brings us down to earth, to reality, every time. Of course, there have been ideas in philosophy that view the final aim of human being in separation of the mind from the body (usually accomplished after death of the body) ${ }^{24}$, but the body has been proving its undeniable role in the cultivation or holistic education of human beings from ancient time to the present ${ }^{25}$. Why? It can be said that the 'golden mean', 'moderation' or 'temperance' is written down in the essence of the acting body itself. We have our own experience that too much or too little food, drink, or bodily activity causes the body to react in the form of pain or illness. Pain is the body's own answer to too much or too little of anything concerning the body itself. The body has its own logic which cannot be denied, at least not in the long run. But there is not only pain when we exceed the limits of comfort. Already, moderate body activity has the power to arouse our senses, helping our consciousness to direct us in the right direction.

When we practice sport it is not possible to separate mind from the body, as it is possible in some other intellectual human activities. And when we are one with the whole body, it can teach us its own logic - the logic of temperance. It is worthy to point out at this juncture that there are in modern sport temptations (recreation) to separate the mind (self) from the body, especially to overcome or to not feel during physical activity discomfort or the body's pain. The most obvious example of that is listening to the music (MP3 players) while practicing a sport such as running. This means that the mind flies away from the signals the body is giving us. As an excuse it is often said that running is boring. Yes, but only if you are blind to the environment around you and if you do not listen to your body while you are running. I argue that those who run with 'music in their ears' only get partial benefits from the running, because they are training the body like a machine, separated from their selves. Because sport is connected with the body, and because sport demands that one listens to the body, the body can teaches us its inherent temperance.

So, the first source of temperance in sport derives from the body. The second origin of temperance in sport can be recognized in the nature of sport as toward an end-directed activity. When people practice sport, they often practice it with some final purpose in their mind, e.g. the better performance, health, regulation of body or weight, etc. And this final purpose we desire has the power to limit and direct our ordinary, daily activities. It gives us special motivation to reach the goal, yet nevertheless it demands from us at the same time restrictions as our desires of ordinary life do. We must rationally subordinate ourselves to higher ends; this is the original meaning of temperance, as it was said: the essence of temperance is to gain inside order in the longing for final purpose.

\footnotetext{
${ }^{24}$ See Plato's philosophy as a paradigmatic example of such view.

${ }^{25}$ For Plato physical education have a great role in cultivation of virtue of fortitude. See: Plato Laches 181-190.
} 
Of course, there are different kinds and origins of sport. One which is more directed to the play activities, which have their aim in themselves and therefore can be compared to contemplation (Tugwell 1988, p. 527), while the other can be understood as a mean to other ends: sport as an enddirected activity. In this second sense sport can be work for earning money (professional sports), a source of recreation or rest after work in order to prepare for new work (recreational sports), a means of education (physical education) or a means of health (good physical conditioning, regulation of body weight, etc.). This kind of sport - sport as a means - has great impact, especially on the cultivation of temperance in human being, because athletes must rationally subordinate themselves to higher ends. It also seems that individual sports do better in developing temperance than team sports do; namely, temperance is the virtue directed to the self (Pieper 1965, p. 147). The rise of popularity of individual sport is supported with the growth of individualization and atomization in society. Charles Taylor presented this in his book The Ethics of Authenticity (2003) in which he writes about the three malaises of modernity also recognized in the development of modern sport. First is 'individualism', which corresponds to the modern understanding of sport as an individual activity. ${ }^{26}$ It is not surprising, therefore, that the individual sport activities, like fitness or jogging, became so popular in the second half of twentieth century. And these are sports that can be a perfect individual means to develop temperance. Moreover, they correspond to the second malaise of modernity, which is 'instrumental reason'. By this Taylor means "the kind of rationality we draw on when we calculate the most economical application of means to a given end. Maximum efficiency, the best cost-output ratio, is its measure of success" (Taylor 2003, p. 5). In modern sport it is recognized in the end-directed physical activities, e.g. sport for money, sport for education, sport for health, sport for loss of body weight, etc. The usefulness of sport is therefore perceived in terms of efficiency or 'cost-benefit' analysis ${ }^{27}$. Because of that temperance is often recognized as a moral ideal in modern (sport) society. In this sense Hosta talks about the 'moralization of human body', which is, strictly speaking, the other name for the need of temperance in human life: "Moralization speaks about the fact, that fatness, obeseness or any kind of unhealthy body is a sign of moral weakness (indiscipline or disorder)" (Hosta 2009, p. 12). That is, the lack of temperance in a human being. It is obvious, then, that to strive for temperance can help us in gaining self-knowledge, namely we must face different tensions in ourselves and order them. And this is an important step in self-fulfillment.

\section{Sport, temperance and truth}

As we have seen, sport and other physical activities can help to cultivate the virtue of temperance in human beings. However, to be temperate (or to have temperance) is not the final aim of human life. Temperance is one mean to higher ends, like knowledge of truth and happiness.

Since the ancient philosophers, it has been known that temperance is closely connected with the problem of human knowledge, not only with 'desires and pleasures'. When Aquinas said that the virtue of temperance orders one's appetites rightly with respect to food, drink and sexual relations, he knew that unordered life in these areas has a great impact on the human capability to grasp truth. If one's appetites became disordered, then one becomes disposed to seek what is bad under the impression that it is good (Fritz and Cates 2002, p. 323). Aquinas emphasized that disordered pleasures "dim the light of reason from which all the clarity and beauty of virtue arise: wherefore these pleasures are described as being most slavish" 28 . Therefore, temperance (gained during sport practice) is a virtue enabling human being to recognize truth. Moreover, because the right amount of humility is one of the essential characteristics human beings must have to make good relationships with others, temperance can help us in realizing this task. Sport can be perfect source to teach us truth about our

\footnotetext{
${ }^{26}$ Of course, individualism as such many people consider the finest achievement of modern civilization... (Taylor 2003, 2).

${ }^{27}$ The third malaise of modernity is the loss of freedom, mainly on a political level (Taylor 2003, 8).

${ }^{28}$ Aquinas, Summa Theologicae, IIa IIae, q. 142, a. 4.
} 
self if we agree with Pieper that "the ground of humility is man's estimation of himself according to truth" (Pieper 1965, p. 189). In sport we necessarily face our limits, on both the physical and mental levels. In competitive sport, sooner or later everyone experiences defeat; in recreational sport everybody must face his physical limits of body and will. It is not possible to be the winner all the time or to run for hours and hours without rest. And this opens the athlete to the knowledge of the truth about self and to humility. On this ground openness to the other person becomes more possible. It is common practice that athletes become friends and make different communities. Sport also unites different people because people have similar interests and similar experiences after being active in sport.

\section{The final aim of temperance in sport: happiness}

If we now collect all the benefits of temperance in sport, namely attaining our goals, knowledge of truth, good relations etc., there is still one final meaning indicating why it is wise to strive for temperance: happiness. Happiness is, as all classical philosophies assert, the final aim of human life. The connection between temperance and happiness may not be clear at first glance; however they are strongly connected. As we have said, it is the role of temperance to help human beings abandon unnecessary things in life and strive for those important elements. In short: "The purpose and goal of temperantia is man's inner order, from which alone this 'serenity of spirit' can flow forth. 'Temperance' signifies the realizing of this order within oneself." (Pieper 1965, p. 147). Therefore, temperance makes possible for man to live according to his innate natural order, which can only give true happiness.

Now the question for all of us arises: Does sport activity - as a mean for gaining temperance really bring happiness to the human life? If it does, what kind of sport does so? In what/which situation? If it does not, why not? What is wrong - if it is wrong - with that particular sporting activity? In other words, we can ask ourselves if some particular sporting activity really help people to "dispose various parts into one unified and ordered whole," (Pieper 1965, p. 146) which is the primary and essential meaning of temperare? Do sporting activity restore what was devastated by the 'gratification of the palate', namely, the inner form of man. The measuring tool for that should be the 'cheerfulness of the heart' hilaritas mentis or true happiness, gained with the particular sporting activity. Therefore, joy and happiness derived from sporting activity can be outer signs of inner order, of temperance. If any sporting activity leads to real harmony inside of human being, this must be shown in outside happiness, namely this man gains the inner self-fulfillment - the fulfillment of human nature. Does your sport realize this final aim?

\section{Conclusion}

More and more people are convinced that sport has enormous educational power. Therefore the role of sport today could be even more important because - as it is often said - education is in crisis. Weiss asserted some time ago that athletics not only builds bodies but character (Weiss 1969, p. 28). Sport moulds human beings through bodily exercise in different ways. And the development of temperance - which sport can promote - seems one of the most important tasks for modern man and society as a whole. Therefore it is important to know that sport can give us some solutions for modern problems - not always, not completely, but it can. And that is important.

\section{REFERENCES}

Aquinas, T. (1225-1274). Summa Theologicae. Public Domain. Retrieved May 25, 2010, from http://www.ccel.org/ccel/aquinas/summa.html.

Aristotle (2004). Nicomachean Ethics. Cambridge: Cambridge University press.

Augustine, De civitate dei. London: Aris \& Phillips.

Bentham, J. (1996). An Introduction to the Principles of Morals and Legislation. Oxford: Clarendon Press. 
Curzer, H. J. (1997). Aristotle's account of the virtue of temperance in Nicomachean Ethics III.10-11. Journal of the History of Philosophy, 35(1), 5-25.

Fritz Cates, D. (2002). The Virtue of Temperance. In J. S. Pope (Ed.), The Ethics of Aquinas (321-339). Washington, D.C.: Georgetown University Press.

Gough, R. W. (1996). Character is Everything: Promoting Ethical Excellence in Sports. Wadsworth Publishing. Hall, T. C. (2003). Asceticism. In Encyclopedia of Religion and Ethics, Part 3. New York: Kessinger Publishing. Hosta, M. (2007). Etika športa. Manifest za 21. stoletje. Ljubljana: Fakulteta za šport.

Hosta, M. (2009). Od fitnessa preko welnessa in selfnessa k playnessu. Šport, (3-4), 12.

Kent, B. (2002). Habits and Virtues. In J. S. Pope (Ed.), The Ethics of Aquinas (116-130). Washington, D.C.: Georgetown University Press.

Kocijančič, G. (2002). Platon. Celje: Mohorjeva družba.

Pieper, J. (1965). The Four Cardinal Virtues. New York: A Helen and Kurt Wolff Book.

Plato (2004). Republic. Indianapolis: Hackett Publishing Company.

Quinn, P. L. (1998). Asceticism. In Routledge Encyclopedia of Philosophy (Version 1.0). London and New York: Routledge.

Reale, G. (2002). Zgodovina antične filozofije: Platon in Aristotel. Ljubljana: Studia humanitatis.

Stevenson, L., Haberman, D. L. (2009). Ten theories of human nature (5th ed.). Oxford: Oxford University Press.

Sweet, W. E. (1987). Sport and Recreation in Ancient Greece: A source book with translation, Oxford, New York: Oxford University Press.

Taylor, C. (2003). The Ethics of Authenticity. London: Harvard University Press.

Tugwell, S. (1988). Albert \& Thomas: Selected Writings. New York: Paulist Press.

Weiss, P. (1969). Sport: A Philosophic Inquiry. Southern Illinois: University Press.

AUTHOR'S ADDRESS: Jernej Pisk

Faculty of Arts - University of Ljubljana

12 Kongresni Trg

Ljubljana 1000, Słowenia

Email: jernej.pisk@gmail.com 